\title{
The Efficacy of Lowering Blood Glucose Levels Using the Extracts of Fermented Bitter Melon in the Diabetic Mice
}

\author{
Hye Seon Park · Woo Kyeong Kim • Hyun Pyo Kim · Young Geol Yoon* (D)
}

\section{당뇨 마우스에서 여주발효추출물의 혈당 강하 효능}

박혜선 · 김우경 · 김현표 · 윤영걸*

Received: 4 June 2015 / Accepted: 16 July 2015 / Published Online: 30 September 2015

(C) The Korean Society for Applied Biological Chemistry 2015

\begin{abstract}
Momordica charantia, commonly known as bitter melon, has interesting pharmacological activities such as anticancer, antiviral, antibacterial, anti-inflammatory, analgesic, and antioxidant. As supported by recent scientific reports on the beneficial effects of $M$. charantia, it is one of the most promising functional plants for diabetes today. In this study, we fermented the bitter melon with lactic acid bacteria and investigated the capability of controlling diabetic conditions by decreasing the blood glucose levels. After extracting the fermented bitter melon with hot water or ethanol, we tested several biological activities using mouse models. When we tested the efficacy of the glycemic control, the extracts of fermented bitter melon significantly lowered the blood glucose levels of the alloxan-induced diabetic mice. We also found that the lactic acid bacteria-fermented bitter melon protected liver damages from the treatment of alloxan monohydrates and maintained low levels of triglycerides and high levels of HDL cholesterol in these mouse models. These results suggest that our approach on fermenting bitter melon and the extracts of fermented bitter melon could lead to the possibility of the development of functional foods that contain the effectiveness of controlling blood glucose and lipid levels as well as preventing liver damages.
\end{abstract}

\section{H. S. Park and W. K. Kim contributed equally}

H. S. Park · W. K. Kim · H. P. Kim · Y. G. Yoon*

Department of Biomedical Science, Jungwon University, 85 Munmu-ro, Goesan-eup, Goesan-gun, Chungbuk 367-700, Republic of Korea

*Corresponding author (Y. G. Yoon: youngyoon97@gmail.com)

This is an Open Access article distributed under the terms of the Creative Commons Attribution Non-Commercial License (http://creativecommons. org/licenses/by-nc/3.0/) which permits unrestricted non-commercial use, distribution, and reproduction in any medium, provided the original work is properly cited.
Keywords alloxan · anti-diabetic - fermentation - lactic acid bacteria $\cdot$ Momordica charantia

\section{서 론}

당뇨병(diabetes mellitus, DM)은 포도당 대사 이상으로 인하여 발생하는 질병으로, 체내 인슐린 부족으로 유발된 인슐린 의존 형 당뇨병인 제1형 당뇨병(insulin-dependent DM, IDDM)과 유 전적이거나 비만 등으로 인해 인슐린 수용체에 이상이 나타나서 인슐린 저항성 같은 신호전달의 문제로 파생된 인슐린 비 의존 형 당뇨병인 제2형 당뇨병(non-insulin-dependent DM, NIDDM) 으로 분류된다(Hue 등, 2009). 우리나라의 경우 성인 약 10 명 중 1 명이 당뇨환자이며 당뇨 유병률은 해마다 늘어나고 있다. 고령화 사회로 진입하면서 2050년에는 예상 당뇨병 환자수가 약 600만명까지 늘어날 것으로 예측되고 있다(Lee와 Park, 2014). 인슐린은 췌장의 베타세포에서 생성되는 호르몬으로서 세포의 포도당 이용 및 혈당강하에 있어 가장 중요한 물질이다. 당뇨환자는 인슐린 부족이나 저항성으로 인해 혈중 포도당 농 도가 높게 유지되고, 지속적인 고혈당이 지질과 단백질의 대사 이상, 신장 기능저하, 동맥경화, 시력저하 등 실생활을 어렵게 하는 다양한 합병증을 유발한다. 당뇨병은 현재 완치가 어려우 며, 식이요법이나 운동요법으로 혈당치를 조절하여 예방하거나 대부분의 당뇨환자가 경구 혈당 강하제를 지속적으로 복용하여 당뇨병의 악화를 지연시키고 있다(Meena 등, 2009). 그러나 대 표적인 당뇨병 치료약인 설폰요소제(sulfonylurease), 비구아나이 드(biguanides), 아카보즈(acarbose), 다이아자이드(thiazide) 계열 의 약품은 한 두 군데의 신진대사 과정에만 인위적으로 작용하 기 때문에, 부작용과 내성을 피할 수 없다(Lee 등, 2013). 이와 같은 문제를 해결하기 위해 최근에는 천연물을 이용하여 보다 안전한 혈당 강하제를 개발하려고 하는 추세이며(Kim과 Lee, 
2011) 더덕 추출물이 제2형 당뇨에 미치는 영향(Yun 등, 2014), 뽕잎과 녹차 혼합 분말의 항당뇨 효과(Son 등, 2014), 한약 복 합체 추출물의 혈당 강하 효과(Lee 등, 2014) 등의 천연물을 이 용한 항당뇨 연구가 보고된 바 있다. 최근 들어 천연물을 이용 한 항당뇨 연구가 진행됨에 따라 천연 인슐린이라 불리는 여주 도 항당뇨 효과가 있는 천연물로 각광받고 있으며, 미국과 한 국에서 혈당 강하를 위한 음료와 차 등으로 사용되고 있다(Lee 등, 2012). 이와 같이 여주가 민간에서 널리 사용되고 있는 상 황에 비해 여주의 이용 및 효능에 관한 과학적 분석 연구 등은 아직 미미한 실정이다.

여주(Momordica charantia)는 박과에 속하는 한해살이 덩굴 성 풀로서 잎은 크고 콩핕 모양의 원형인 모양을 가지고 있으 며, 길이와 너비는 약 5-12 cm이고 일반적으로 5-7개의 깊은 갈래가 있다. 열매는 긴 타원형 모양이거나 난형이며 양끝이 모 두 좁고, 길이는 8-30 cm로 자라며 전체가 뭉뚝하고 혹 모양의 도드라진 돌기가 무작위로 덮여 있다. 여주는 또한 고과(苦瓜) 로 불리기도 하며 특히 여주를 영어권에서는 "bitter melon"이라 불린다. 일본에서는 ‘니가우리', 오키나와 방언으로는 ‘고야', 필 리핀에서는 ‘암팔라야', 인도에서는 '카라벨라', 태국에서는 '마 라라고 불리며 열대 아시아, 아프리카, 지중해 등에서 재배가 되는 섭취 가능한 과일로 그 맛이 매우 쓰므로 비터멜론으로 알려져 있다(Lee 등, 2009; Kim, 2013). 또한 비타민 C, 사포 닌, 알칼로이드, 글루코사이드 등의 유용물질을 다량 함유하고 있으며, 특히 혈당 강하 기능이 있는 카란틴이라는 성분이 높 게 함유되어 있다고 알려져 있다(Lee 등, 2012).

현재 유용 미생물을 이용해 천연물의 생리활성을 증진시키는 주요한 기술로 발효가 널리 이용되고 있고, 발효 녹차의 항당 뇨 효과(Lee 등, 2014)와 발효버섯의 항산화 활성(Yang 등, 2014) 등 발효를 통해 기능성을 증진시킨 연구가 보고된 바 있 다. 그러나 현재까지 여주는 여주추출물과 과즙을 이용한 연구 만 보고 되었을 뿐, 발효시킨 여주의 기능성 증진 효과에 관한 연구는 아직 보고된 바가 없다. 이에 본 논문에서는 여주의 항 당뇨 효능 증진을 위해 유산균(Lactobacillus plantarium)을 이 용해 발효하고 열수와 에탄올로 추출한 후 당뇨 마우스 모델에 여주 발효추출물을 투여하여 혈당 강하 효능, 간기능 개선 여 부와 지질의 변화 등을 분석하여 여주 발효추출물의 기능성식 품 소재개발에 대한 가능성 연구를 수행하였다.

\section{재료 및 방법}

추출물의 제조. 여주는 국내에서 재배된 것을 경동시장에서 구 매하여 사용하였다. 건여주를 믹서기로 분쇄하여 분말화한 후 여주 $100 \mathrm{~g}$ 당 유산균(Lactobacillus plantarium) 약 $1 \times 10^{7}$ 개를 혼합하고 3 배수의 물을 첨가하였다. 이 혼합물을 96시간 동안 $30^{\circ} \mathrm{C}$ 에서 발효한 후, 열수 또는 에탄올 $(30 \%)$ 을 이용하여 교반 추출하고 추출물을 여과 및 감압농축 $(0.5 \mathrm{~g} / \mathrm{mL})$ 하여 여주발효열 수추출물(bitter melon fermented and boiled water extracts, $\mathrm{BMB}$ )과 여주발효에탄올추출물(bitter melon fermented and ethanol extracts, $\mathrm{BME}$ )을 제조하였다. 대조군인 여주열수추출물 (bitter melon boiled water control, $\mathrm{BMBC}$ )과 여주에탄올추출 물(bitter melon ethanol control, $\mathrm{BMEC}$ )은 유산균을 첨가하지 않고 동일한 방법으로 제조하였다.

실험동물. 생후 5주령의 imprinting control region mouse를 (주)
대한바이오링크로 부터 구입한 후, 온도 $18 \pm 2^{\circ} \mathrm{C}$, 상대습도 $50 \pm 10 \%$, 환기회수 $10-20$ 회/시간, 조명시간 12시간(점등 08:00소등 20:00)으로 설정된 동물실에서 환경적응을 위해 1주일간 예비 사육 후 평균 체중 $30-40 \mathrm{~g}$ 의 마우스를 사용하였다. 실험 동물의 사육과 사용 등 실험과정은 중원대학교 동물윤리위원회 의 승인을 받았고, 윤리위원회의 규정에 저촉되지 않게 실시하 였다.

당 유발 마우스의 제조. 생후 6주령의 마우스를 alloxan monohydrate (Sigma Aldrich, USA) $120 \mathrm{mg} / \mathrm{kg}$ 을 복강 투여하여 당뇨를 유 발시킨 후, 72 시간 후 쥐의 꼬리에서 혈액을 채취하여 개인용 혈당측정 시스템(Infopia Co., Korea)을 이용하여 glucose 수치 를 측정하였다. Glucose 수치는 측정하기 8-12시간 전에 사료 를 빼주어 8-12시간 정도 공복 상태 후 측정하였으며, 혈당수 치가 $160-180 \mathrm{mg} / \mathrm{dL}$ 인 것을 정상으로 보았고, 혈당수치가 200$600 \mathrm{mg} / \mathrm{dL}$ 까지 증가한 것을 당뇨가 유발된 것으로 간주하고 실 험에 사용하였다.

효능 검증. 마우스 실험의 실험군은 여주열수추출물(BMBC), 여 주발효열수추출물 $(\mathrm{BMB})$, 여주에탄올추출물(BMEC), 여주발효 에탄올추출물 $(\mathrm{BME})$ 투여군으로 하였고 대조군은 정상 마우스 군(normal control, NC)과 alloxan monohydrate 투여 마우스군 (alloxan control, AC)으로 하였다. 추출물의 투여는 oral zonde 를 이용하여 $0.5 \mathrm{~g} / \mathrm{mL}$ 농도의 추출물을 $200 \mu \mathrm{L}$ 씩 4 주 동안 매 일 한번씩 경구투여를 하였고, 1 주일에 한번씩 혈당과 몸무게 를 측정하였다.

AST 및 ALT 측정. 혈중 aspartate aminotransferase (AST)와 alanine aminotransferase (ALT)의 함량은 4주 동안의 경구투여 가 끝난 마우스를 ethyl ether로 마취 후 흥부를 열어 심장에서 혈액을 채취하여 $13,000 \mathrm{rpm}$ 으로 원심 분리한 후 혈청을 분리 하여 $-80^{\circ} \mathrm{C}$ 에 냉동 보관하여 분석에 사용하였다. 혈장 $\mathrm{AST} /$ ALT 측정용 키트(ASAN pharmaceutical co Ltd., Korea)를 사 용하여 Reitman-Frankel 법을 이용하여 분석한 후 $505 \mathrm{~nm}$ 에서 흡광도를 측정하였다.

혈장 지질 분석. 간의 지질분석을 위해 혈청 채취는 4 주 동안 의 경구투여가 끝난 마우스를 ethyl ether로 마취 후 흉부를 열 어 심장에서 혈액을 채취하여 $13,000 \mathrm{rpm}$ 으로 원심 분리한 후 혈청을 분리하여 $-80^{\circ} \mathrm{C}$ 에 냉동 보관하여 분석에 사용하였다. 혈 중 중성지방 $(\mathrm{TG})$ 함량 측정은 중성지방 측정용 키트(Asan pharmaceutical co Ltd.)를 이용하여 enzymatic method로 분석 후 $550 \mathrm{~nm}$ 에서 흡광도를 측정하였고, total cholesterol (T-CHO) 함량 측정은 전체 콜레스테롤 측정용 키트(Asan pharmaceutical co Ltd.)를 이용해 enzymatic method로 분석 후 $500 \mathrm{~nm}$ 에서 흡광도를 측정하였고, HDL-cholesterol $(\mathrm{HDL})$ 함량 측정도 키 트(Asan pharmaceutical Co., Ltd.)를 이용하여 enzymatic method으로 분석 후 $500 \mathrm{~nm}$ 로 흡광도를 측정하여 분석하였다. 통계 처리. 결과의 통계학적 분석은 graph pad prism 5.0 프로 그램을 이용하여 실시하였다. 모든 측정 항목의 결과는 평균 (mean)표준편차(standard deviation, $\mathrm{SD}$ )로 표시하였고 대조군과 실험군간의 평균 차이는 one-way ANOVA로 유의성을 확인한 후 $p<0.05$ 수준에서 유의성 검증을 하였다.

\section{결과 및 고찰}

항당뇨 효능 검증. Alloxan $(120 \mathrm{mg} / \mathrm{kg}$ body weight)을 복강 


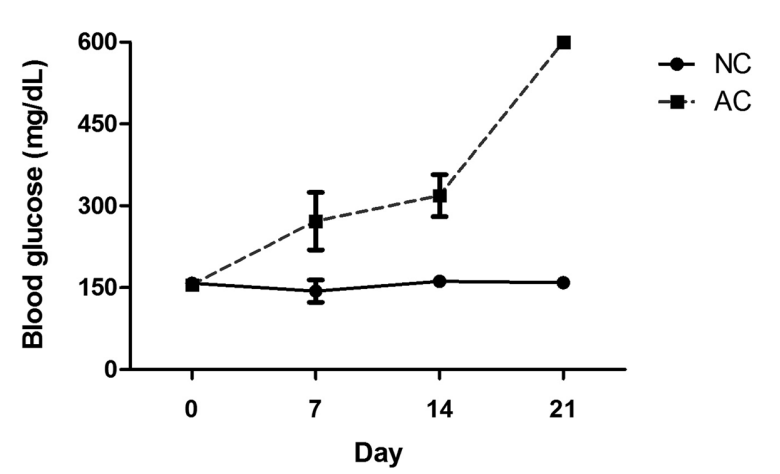

Fig. 1 Generation of the alloxan-induced mouse models. Alloxan monohydrates $(120 \mathrm{mg} / \mathrm{kg})$ was intraperitoneally administered to six week-old mice and then the blood glucose levels were determined. The blood glucose levels in the mice of alloxan control (AC) were continuously increased whereas the levels in the normal control (NC) were stably maintained. Data expressed as the mean $\pm \mathrm{SD}(n=7)$.

투여하고 약 3-7일에 한번씩 혈당을 측정하여 혈당수치가 200$600 \mathrm{mg} / \mathrm{dL}$ 의 범위로 상승한 마우스를 당뇨가 유발되었다고 판 단하여 실험에 사용하였으며(Fig. 1), 각 군의 혈당 평균치가 비 슷하도록 실험동물을 나누었다. 여주열수추출물(bitter melon boiled water control, BMBC), 여주발효열수추출물(bitter melon fermented and boiled water extracts, $\mathrm{BMB})$, 여주에탄올추출물 (bitter melon ethanol control, BMEC)과 여주발효에탄올추출물 (bitter melon fermented and ethanol extracts, BME)을 당뇨를 유발한 마우스에게 4주 동안 경구투여를 수행하였고, 동시에 일
주일에 한번씩 8-12시간 동안 절식시킨 상태에서 혈당수치와 몸무게의 변화를 측정하였다(Fig. 2, 3). 또한 실험 기간 동안 대조군과 실험군의 음수량과 식이량의 변화를 측정하였다 (Fig. 4).

Fig. 2에서 보듯이 $\mathrm{NC}$ 군 $(158.6 \pm 1.5 \mathrm{mg} / \mathrm{dL})$ 의 당 수치와 유사 하게 $\mathrm{BMB}(183 \pm 33.5 \mathrm{mg} / \mathrm{dL})$ 를 투여한 군에서만 뚜렷한 혈당 강하 효과가 보였다. 이 결과는 여주발효열수추출물이 혈당 상 승을 억제하거나 정상치를 유지하는데 탁월한 효능이 있음을 의 미한다. 반면에 그 외의 $\mathrm{BMBC}(339 \pm 4 \mathrm{mg} / \mathrm{dL}), \mathrm{BMEC}(329.2 \pm$ $42.9 \mathrm{mg} / \mathrm{dL}), \mathrm{BME}(390 \pm 221 \mathrm{mg} / \mathrm{dL})$ 의 투여군에서는 $\mathrm{AC}$ 군 $(317.8 \pm 28.7 \mathrm{mg} / \mathrm{dL})$ 과 비교하여 명백한 혈당강하 효능은 보이지 않았다. 이는 여주의 유산균 발효 과정에서 항당뇨 기능을 갖 는 유효 성분의 활성이 증가한 형태이거나 흡수 또는 추출이 용이한 형태로 전환된 결과로 사료된다. 따라서, 추후 연구에서 유산균 발효로 인한 여주 유효 성분의 변화에 관한 연구가 필 요할 것으로 보인다. 한편 당뇨로 인한 체중감소가 나타나는 지 를 확인한 결과, 체중의 변화는 모든 군에서 눈에 띄는 변화가 나타나지 않았고, 이를 통해 alloxan에 의한 당뇨 또는 $\mathrm{BMB}$ 에 의한 혈당 강하가 체중의 변화에는 크게 영향을 미치지 않는 것을 관찰하였다(Fig. 3). 이와 같은 결과는 본 실험이 4주 동 안의 비교적 단기간으로 진행되었기 때문으로 생각되며, 당뇨병 은 만성질환으로 장기적인 관리가 필요함을 감안할 때 추후 연 구에서 여주추출물이 혈당 및 체중에 미치는 장기적인 영향이 연구 되어야 할 것으로 사료된다.

더불어 대조군( $\mathrm{NC}$ 군과 $\mathrm{AC}$ 군)과 실험군(BMBC, $\mathrm{BMB}, \mathrm{BMEC}$ 과 $\mathrm{BME}$ 투여군) 사이의 음수량의 변화를 관찰한 결과, $\mathrm{BMB}$ 투여군에서 혈당강하 효과가 나타나기 시작하는 2주째가 되는
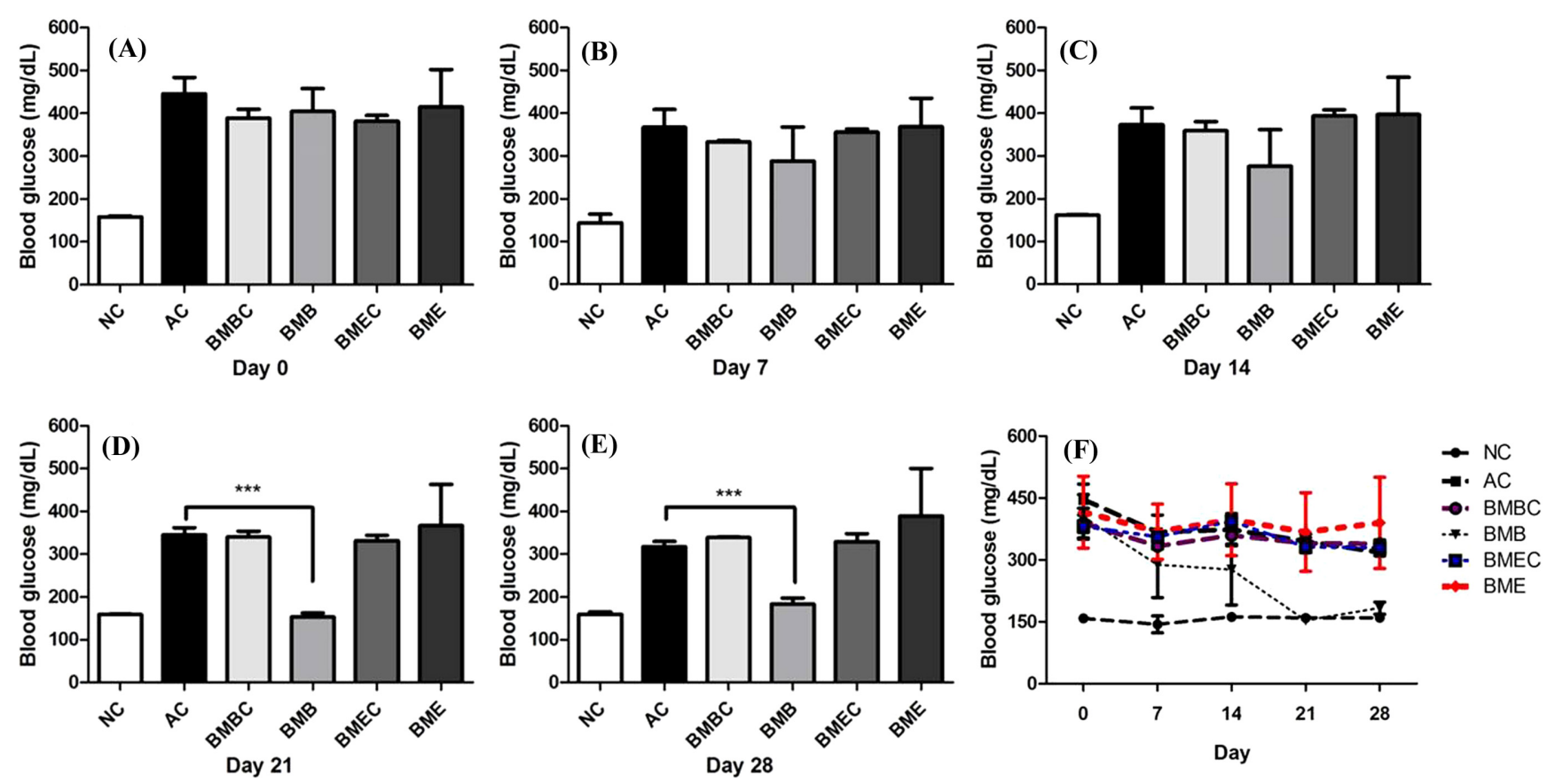

Fig. 2 Changes of the blood glucose levels. The extracts of bitter melon were supplied to diabetic mice by oral administration for four weeks. (A-E) Blood glucose levels at day $0,7,14,21$, and 28 , respectively. (F) Changes of the blood glucose levels represented by a line graph. The blood glucose levels in the mouse group provided with the fermented and boiled water extracts (BMB) clearly decreased to normal glucose levels within 21 days $(* * * p<0.001)$. Other mouse groups (BMBC, BMEC, and BME) showed no clear tendency of decreasing blood glucose levels (NC, normal control; $\mathrm{AC}$, alloxan control; BMBC, bitter melon boiled water control; BMB, bitter melon fermented and boiled water extracts; BMEC, bitter melon ethanol control; BME, bitter melon fermented and ethanol extracts). Values are mean $\pm \mathrm{SD}(n=7)$. 

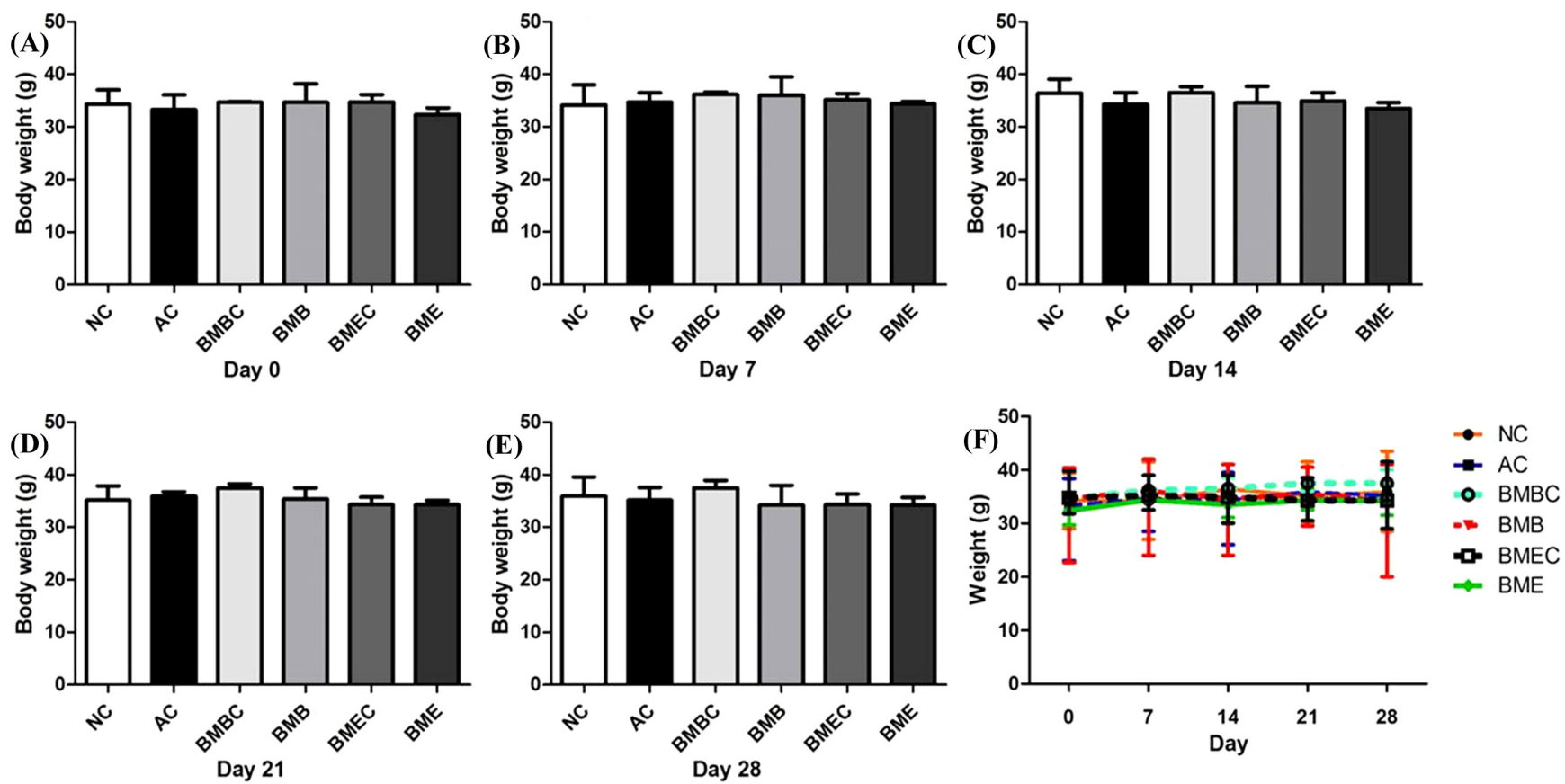

Fig. 3 Changes of the body weights. (A-E) Body weights at day 0, 7, 14, 21 and 28, respectively. (F) Changes of the body weights represented by a line graph. The body weights of the five mouse groups (AC, BMBC, BMB, BMEC and BME) were similarly maintained as the normal control (NC). No obvious changes in the body weights of the mouse groups were seen during the experiment. Values are mean $\pm \mathrm{SD}(n=7)$.
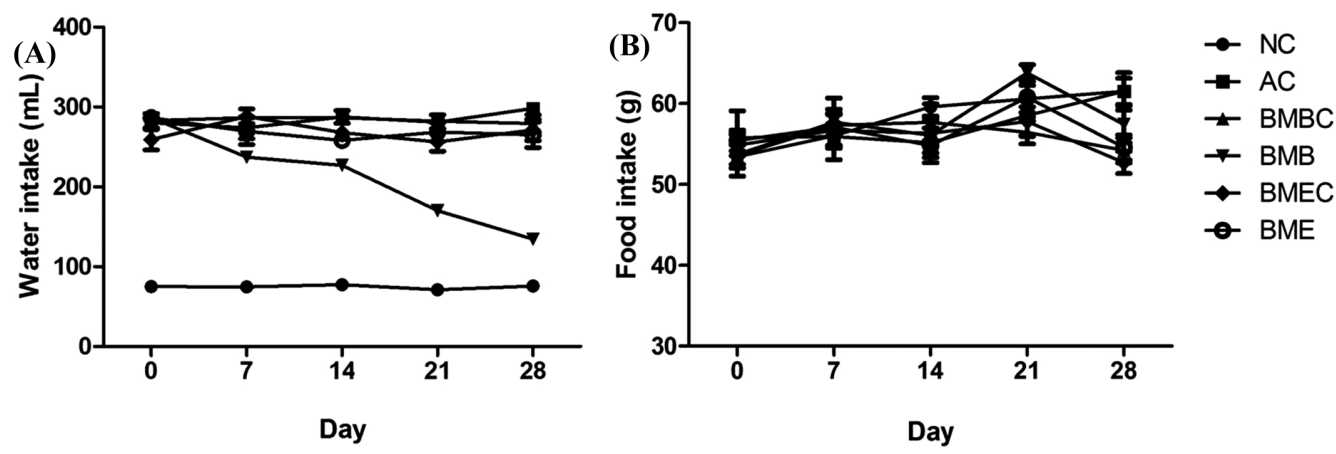

Fig. 4 Water and food intake levels in the diabetic mice. During the oral administration of the extracts of bitter melon, water (A) and food (B) intake levels were measured at the same time intervals. The water intake level of the BMB group gradually decreased to the level of normal control (NC) during four weeks. Other mouse groups (BMBC, BMEC, BME, and $\mathrm{AC}$ ) showed no obvious tendency of decreasing water intake levels during the experiment. In contrast, all of the six mouse groups (NC, AC, BMBC, BMB, BMEC, and BME) showed similar levels of food consumption during the experiment. Values are mean $\pm \mathrm{SD}(n=7)$.

시기부터 음수량도 또한 감소하는 경향을 보였고 4주가 되는 시기에는 정상 대조군인 $\mathrm{NC}$ 군의 수준으로 감소하는 경향을 보 였다(Fig. 2A, 4A). 그러나 BMBC, BME, BMEC 투여군 및 $\mathrm{AC}$ 군들은 $\mathrm{NC}$ 군과 비교하여 약 3 배 정도 음수량이 많았고 $\mathrm{BMB}$ 투여군과는 다르게 음수량이 감소하는 경향을 보이지 않 았다. 이러한 결과는 당뇨가 유발 되면서 모델동물의 음수량이 증가하는 양상을 보이다가 혈당이 감소하면서 음수량도 줄어드 는 기존의 결과와 유사한 양상을 보였다(Lee 등, 2010; Tian 등, 2010). 하지만 식이량은 단순 시간에 따라 마우스들이 성장하면 서 조금씩 늘어나는 정도였고 각 군별로도 크게 차이를 나타내 는 양상을 보이지 않았다(Fig. 4B).

AST 및 ALT 측정. 혈청 중 AST 및 ALT의 수치 증가는 간 손상으로 인하여 증가하게 되며, 간 조직의 괴사와 간 세포의
파괴가 진행됨에 따라 transaminase가 혈중으로 유출되어 높은 수치를 나타내는 것으로 간세포의 변성 및 괴사의 지표로 이용 되고 있다(Park과 $\mathrm{Kim}, 2010)$. 간질환은 당뇨병의 합병증으로 많이 나타나며 이에 따라 AST와 ALT가 증가하므로(Bhatt와 Smith, 2015), 본 실험에서는 여주추출물이 당뇨로 인한 간기능 저하의 개선에 미치는 영향을 알아보기 위해 혈중 AST 및 $\mathrm{ALT}$ 를 조사하였다. 대조군인 $\mathrm{AC}$ 군을 제외한 모든 그룹들이 $\mathrm{NC}$ 군과 비슷한 정도의 수준으로 나타났는데 그 중 $\mathrm{BMB}$ 투여군 이 유의적으로 AST와 ALT를 감소시킴을 알 수 있었다(Fig. 5). 즉, $\mathrm{AST}$ 테스트에서 $\mathrm{AC}$ 군 $(236.0 \pm 108.6 \mathrm{mg} / \mathrm{dL})$ 에 비해 $\mathrm{BMB}$ 투여군 $(53.4 \pm 12.1 \mathrm{mg} / \mathrm{dL})$ 에서 $p<0.01$ 수준에서 유의적인 차이 를 보였고, $\mathrm{BME}$ 투여군 $(61.4 \pm 7.2 \mathrm{mg} / \mathrm{dL})$ 에서도 $p<0.05$ 수준에 서 유의적인 차이를 보였다(Fig. 5A). ALT 테스트에서도 또한 

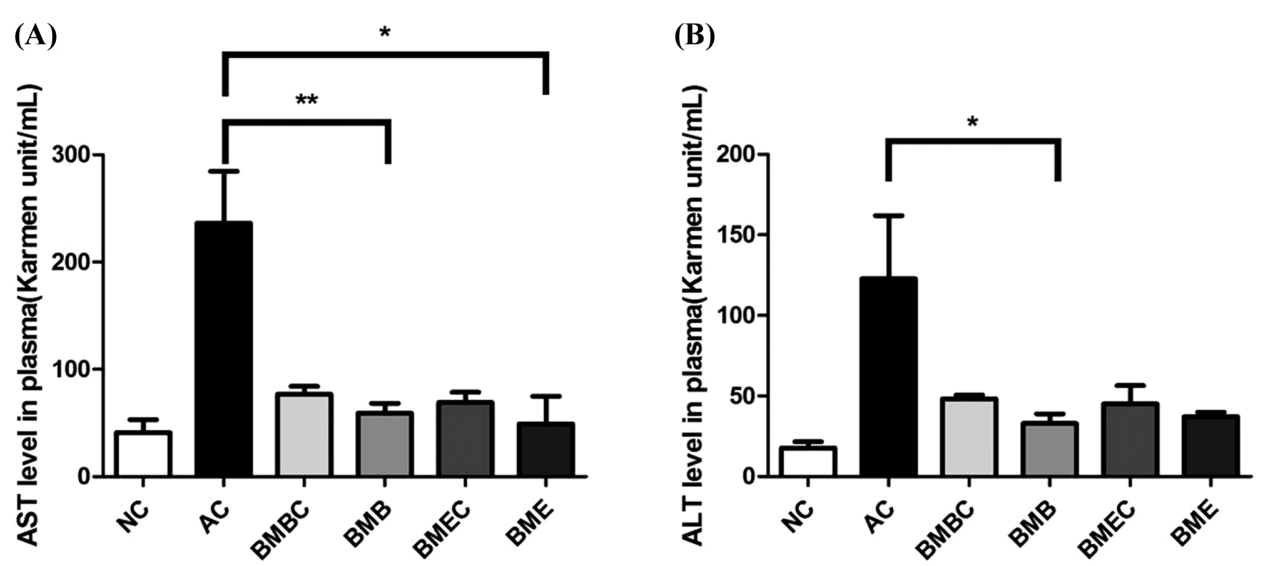

Fig. 5 Serum AST and ALT analyses. The degree of liver injury was demonstrated by the serum AST (A) and ALT (B) levels. Result showed a significant difference between the groups provided with the extracts of fermented bitter melon (BMB and BME) and alloxan control (AC) in the reduction of serum AST and ALT levels. BMB and BME were shown to offer liver protection against alloxan-induced liver injury in mice $(* * p<0.01$ and $* p<0.05)$. Values are mean $\pm \mathrm{SD}(n=7)$.

(A)

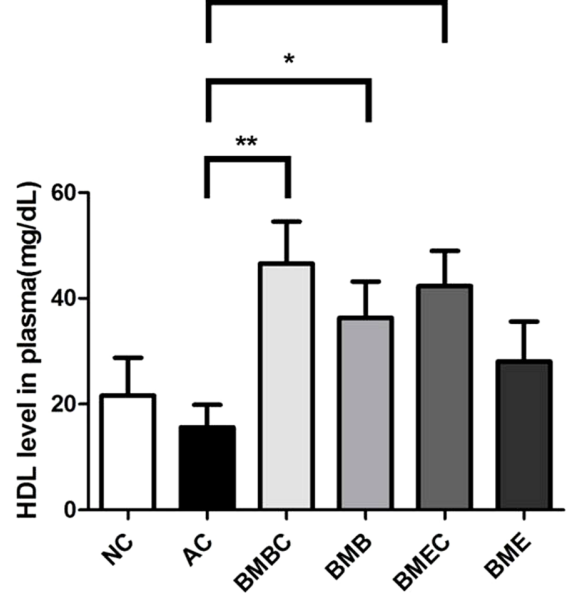

(B)

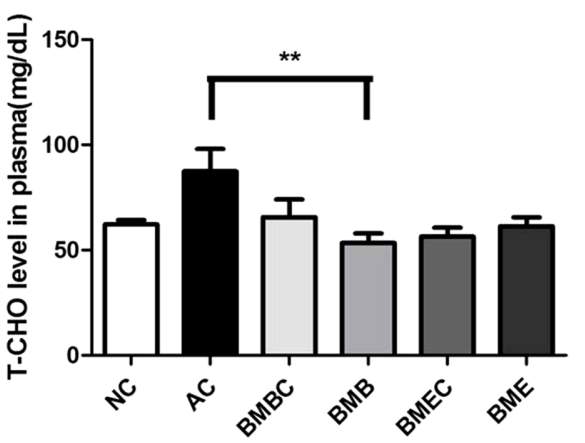

(C)

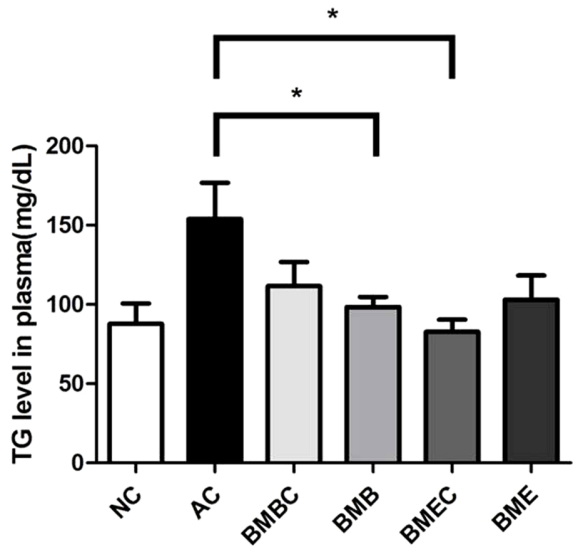

Fig. 6 HDL-cholesterol (HDL) (A), Plasma total cholesterol (T-CHO) (B) and triglyceride (TG) (C) levels of normal or alloxan-induced diabetic mice fed the extracts of bitter melon. Supplement of the boiled water extracts of fermented bitter melon (BMB) significantly decreased the T-CHO and TG levels and increased the HDL levels $(* * p<0.01$ and $* p<0.05)$. Values are mean $\pm \operatorname{SD}(n=7)$.

$\mathrm{AC}$ 군$(122.7 \pm 87.8 \mathrm{mg} / \mathrm{dL})$ 과 비교해서 $\mathrm{BMB}$ 투여군(32.9 \pm 16.0 $\mathrm{mg} / \mathrm{dL}$ )이 $p<0.05$ 수준에서 유의적인 차이를 보였다(Fig. 5B). 이러한 결과는 다른 추출물 투여군과 비교 했을 때 $\mathrm{BMB}$ 와 $\mathrm{BME}$ 투여군이 당뇨로 인한 간 손상을 보다 효과적으로 억제 할 수 있는 효능을 가지고 있음을 의미한다고 사료된다.

혈중 지질 분석. 당뇨병은 만성 대사 질환으로서 혈중 중성지 질 및 $\mathrm{LDL}$ 콜레스테롤은 증가하고 $\mathrm{HDL}$ 콜레스테롤은 감소하 는 특징을 나타낸다. 또한 제 1 형 당뇨환자의 $\mathrm{HDL}$ 수치가 높아 지면 단백뇨 위험을 감소시키는데 영향을 준다는 연구결과가 보 고되어 있다(Molitch 등, 2006). 당뇨병에서 혈장 내 지방이 중 성지방으로 전환되는 속도가 증가하여 혈중 중성지방의 수준이 높아진다는 보고가 있으며, 당뇨쥐에서 지질분해효소의 활성이 저하되면 중성지방이 풍부한 지단백 분해를 감소시켜 $\mathrm{HDL}$ 콜 레스테롤 생성을 억제한다고 알려져 있다. 한국인 당뇨환자의 약 $80 \%$ 가 이상지질혈증을 가지고 있다는 보고가 있으므로, 혈 당 수준과 함께 이상지질혈증의 개선이 당뇨 환자의 합병증을
줄이는 데 큰 도움을 줄 것으로 보인다. 따라서, 본 실험에서 여주추출물 투여로 인한 이상지질대사의 개선효과를 조사한 결 과, 여주추출물과 여주발효추출물을 섭취한 군의 $\mathrm{HDL}$ 함량이 높게 나타남을 보여주고 있다(Fig. 6). 이 중에서도 대조군인 $\mathrm{AC}$ 군 $(15.6 \pm 9.4 \mathrm{mg} / \mathrm{dL})$ 에 비해 $\mathrm{BMBC}$ 투여군 $(46.6 \pm 17.6 \mathrm{mg} / \mathrm{dL})$ 과 $\mathrm{BMEC}$ 투여군 $(42.3 \pm 14.9 \mathrm{mg} / \mathrm{dL})$ 에서 $p<0.01$ 수준의 유의성 이 보여 가장 효과가 좋은 것으로 나타났으며, $\mathrm{BMB}$ 투여군 $(36.3 \pm 18.1 \mathrm{mg} / \mathrm{dL})$ 에서도 $p<0.05$ 수준의 유의성으로 $\mathrm{HDL}$ 수치 가 높게 나타남을 확인하였다(Fig. 6A). T-CHO은 $\mathrm{AC}$ 군과 비 교하여 $\mathrm{BMB}$ 투여군이 $p<0.01$ 수준의 유의성으로 $\mathrm{T}-\mathrm{CHO}$ 함 량을 감소시킴을 알 수 있었다(Fig. 6B). 혈중 중성지방(TG) 함 량은 $\mathrm{AC}$ 군과 비교하여 $\mathrm{BMB}$ 와 $\mathrm{BME}$ 를 투여했을 때 상대적으 로 $\mathrm{NC}$ 군의 수준으로 중성지방 함량이 감소했음을 알 수 있었 다 $(p<0.05)(\mathrm{Fig} .6 \mathrm{C})$. 이러한 결과들은 여주추출물들이 전반적 으로 $\mathrm{T}-\mathrm{CHO}$ 과 중성지방 $(\mathrm{TG})$ 의 함량은 낮추고 $\mathrm{HDL}$ 의 함량은 증가시켜 당뇨병에서 일반적으로 나타나는 이상지질혈증에 대 
한 조절 및 완화 기능이 있음을 의미한다고 사료된다. 당뇨병 에 수반되는 합병증인 심장질환, 고지혈증, 동맥경화증은 당뇨 환자의 주요 사망원인으로도 알려져 있는데, 본 실험결과로 미 루어볼 때 여주발효추출물의 지속적인 투여는 당뇨환자들의 혈 당증가를 조절하는 기능 외에도 당뇨로 인한 혈중 지질함량의 이상에 의한 여러 합병증에 예방 효과가 있을 것으로 사료된다 (Kim 등, 2013).

본 실험에서 우리는 여주발효추출물의 제조를 위해 분쇄한 여주를 유산균과 배합한 후 $30^{\circ} \mathrm{C}$ 에서 96 시간 동안 배양하였다. 유산균의 최적 발효 조건을 확립하기 위해 접종한 유산균이 잘 자라고 있는 지를 24 시간 간격으로 유산균의 수를 비교 분석하 였을 때 96시간까지 유산균의 수가 급격히 증가하고 있음을 확 인할 수 있었다. 96시간 이후로는 유산균 수는 감소하는 경향 을 보였고 따라서 충분한 발효를 위해 96시간 배양한 여주발효 추출물을 이용하여 실험을 진행하였다. 또한 본 실험에서는 유 산균의 최적 배양온도로 $30^{\circ} \mathrm{C}$ 를 사용하였는데 이는 실험에 사 용한 L. plantarium을 김치에서 분리할 때 사용한 온도가 $30^{\circ} \mathrm{C}$ 이었기 때문이며 추후 연구에서 다른 온도 조건이 여주의 유산 균 발효에 미치는 영향도 연구 되어야 할 것으로 사료된다.

또한 본 실험에서 우리는 여주발효추출물의 혈당강하 효능을 당뇨유발 마우스모델을 이용하여 검증하고자 하였다. 여주발효 열수추출물 $(\mathrm{BMB})$ 을 투여한 군들에서는 급격한 혈당 증가를 억 제하거나 감소시켜 혈당 농도를 정상 수준으로 유지하는데 긍 정적인 영향을 주었다. 혈청 $\mathrm{AST}$ 및 $\mathrm{ALT}$ 측정테스트에서 $\mathrm{AC}$ 군을 제외한 모든 그룹들이 $\mathrm{NC}$ 군과 비슷한 수준을 나타내므로 여주발효추출물에 의한 간 독성은 없을 뿐만 아니라, 당뇨 합 병증으로 나타날 수 있는 간기능 저하를 정상 수준으로 회복 시킬 수 있음을 알 수 있었다. 혈중지질 분석결과는 $\mathrm{AC}$ 군에 비 해 전체적으로 $\mathrm{BMB}$ 투여군에서 총 콜레스테롤과 중성지방 함 량은 감소시키고 $\mathrm{HDL}$ 함량은 증진시키는 효과가 가장 유의성 이 있게 나타났다. 이는 당뇨병으로 인해 발생할 수 있는 심혈 관계 합병증 발생을 완화할 수 있음을 나타내는 결과이다. 결 론적으로 본 연구의 결과들은 여주에 유산균 발효를 결합한 새 로운 추출물 제조방법이 여주의 효능을 극대화시킴으로써 혈당 강하와 간 손상 억제 및 혈중 지질 조절 등 당뇨병의 증상 완 화 및 합병증 발생 가능성을 낮추는 결과를 나타냈고, 이를 활 용하여 여주발효추출물을 이용한 건강기능성식품으로의 개발 가 능성이 충분히 있다고 사료된다. 추후 연구에서 대량 생산을 위 한 최적의 여주 발효 조건 확립과 발효 후 기능 성분들의 변화, 효능 기전 등을 분석할 예정이다.

\section{초 록}

비터멜론으로 알려진 여주(Momordica charantia)는 항암, 항바 이러스, 항균, 항염증, 진통 및 산화방지제를 포함한 흥미로운 약리활성이 있다고 알려져 있다. 민간에서 전통적으로 사용된 여주의 효능은 최근에 과학적인 보고에 의해 증명이 되고 있으 며, 현재 당뇨병 예방과 치료를 위해 연구되어야 할 가장 기대 되는 기능성 식물 중 하나이다. 본 연구에서는 여주를 유산균 으로 발효하여 추출하고 이것이 혈당을 감소시켜 당뇨병을 조 절할 수 있는 지를 조사하였다. 발효한 여주를 열수 또는 에탄 올로 추출한 후, 마우스 모델을 사용하여 고혈당 조절 등 여러 가지 생물학적 활성을 테스트를 하였다. 여주발효추출물은 알록
산으로 유도한 당뇨 마우스모델의 혈당을 유의적 수준에서 저 하시켰고, 또한 알록산 처리에 의한 간 손상을 보호하였으며 중 성지방은 낮게 그리고 $\mathrm{HDL}$ 콜레스테롤은 높은 수준으로 유지 하고 있는 것을 발견하였다. 따라서 이러한 결과들은 여주와 유 산균을 결합한 새로운 방법이 여주의 효능을 극대화시킴으로써 혈당 강하와 간 손상 억제 및 혈중 지질 조절 등 건강기능식품 으로서의 개발 가능성이 충분히 있다고 사료된다.

Keywords 모모르디카 카란티아 - 발효 · 알록산 · 여주 · 유 산균

감사의 글 본 연구는 한국산업단지공단 충청지역본부 산업집적지경쟁력강 화사업과 한국연구재단의 이공분야기초연구사업(NRF-2011-0008052 to YGY) 의 지원에 의하여 수행되었습니다.

\section{References}

Bhatt HB and Smith RJ (2015) Fatty liver disease in diabetes mellitus. Hepatobiliary Surg Nutr 4, 101-8.

Hue JJ, Kim JS, Kim SY, Yun YW, Jeong JH, and Lee BJ (2009) Antiglycemic effect of carnosine in diabetic mice. J Food Hyg Safety 24, 391-7.

Kim ES, Bayarmaa Birasuren, and Kim ME (2013) Preventive action of Ribes diacanthum Pall. against high blood glucose level in alloxan-induced diabetic mice $J$ East Asian Soc Dietary Life 23, 53-60.

Kim JO and Lee GD (2011) Hypoglycemic effects of a medicinal herb mixture prepared through the traditional antidiabetic prescription. Korean J Food Preserv 18, 923-9.

Kim MW (2013) Effect of bitter melon on plasma blood glucose and cholesterol levels in streptozotocin induced diabetic rats. $J$ East Asian Soc Dietary Life 26, 704-12.

Lee HH, Cheong MJ, Huh J, Song SY, and Boo HO (2009) Effects of Momordica charantia L. water extracts on the rat liver and kidney with acute toxicated by Lead. Korean J Microscopy 39, 355-63.

Lee HJ, Moon JH, Lee WM, Lee SG, Kim AK, Woo YH et al. (2012) Charantin contents and fruit characteristics of bitter gourd (Momordica charantia L.) accessions. J Bio-enviroment control 21, 379-84.

Lee HS, Kong HJ, Lee EH, Hwang SJ, Jung HA, Kim ML et al. (2014) Hypoglycemic effects of boiled rice made from unpolished rice, job' tear, and extract from medicinal herbs mixture on diabetic rat. Korean $J$ Herbology 29, 59-70.

Lee J and Park H (2014) Relationships between diabetic knowledge, self-care behaviors and $\mathrm{HbAlc}$ in diabetic patients using public hospitals. $J$ Korean Acad Fundam Nurs 21, 243-52.

Lee JT, Ryu JS, Kwak DH, Park YJ, Kang SS, Kim PJ et al. (2010) Effect of Buan mulberry on metabolic improvement in streptozotocin-induced diabetic rats. J Life Sci 20,1750-7.

Lee SY, Park SL, Nam YD, Yi SH, and Lim SI (2013) Anti-diabetic effects of fermented green tea in KK-Ay diabetic mice. Korean J. Food Sci Technol 45, 488-94.

Meena AK, Bansal P, and Kumar S (2009) Plants-herbal wealth as a potential source of ayurvedic drugs. Asian J Traditional 4, 152-70.

Molitch ME, Rupp D, and Carnethon M (2006) Higher levels of HDL cholesterol are associated with a decreased likelihood of albuminuria in patients with long-standing type 1 diabetes. Diabetes Care 29, 78-82.

Park SH and Kim GY (2010) Blood glucose level, insulin content and biochemical variables of complexcity extract from oriental medicinal plants on diabetes rats. Korean J Food Nutr 23, 258-68.

Son HK, Han HJ, and Lee JJ (2014) Anti-diabetic effect of the mixture of mulberry leaf and green teapowder in rats with streptozotocin-induced diabetes. Korean J Food Preserv 21, 549-59.

Tian HL, Wei LS, Xu ZX, Zhao RT, Jin DL, and Gao JS (2010) Correlations 
between blood glucose levels and diabetes signs in streptozotocininduced diabetic mice. Global J Pharmacol 4, 111-6.

Yang HS, Choi YJ, Oh HH, Moon JS, Jung HK, Kim KJ et al. (2014) Antioxidative activity of mushroom water extracts fermented by lactic acid bacteria. J Korean Soc Food Sci Nutr 43, 80-5.
Yun WK, Bae HJ, Kim YJ, Kwon JO, Im MH, Cho HD et al. (2014) Effect of the supplementation of Coconopsis lanceolata extract on lipid metabolism amelioration in type 2 diabetes mouse model induced by high fat diet. Korean J Food Preserv 21, 107-13. 